(C) 1989 ISIJ

/IIIIIIIIIIIIII/I

論 文

||/IIIIIIIIIIIIIII

\title{
ほうろう層の泡発生機構
}

\author{
和田 忠義 $*$. 押見 正一 ${ }^{*} \cdot$ 後藤 俊助 $* 2$
}

\section{Mechanisms for Evolution of Bubble in Porcelain Enamels}

Tadayoshi WADA, Masakazu OSHIMI and Shunsuke GoTō

\section{Synopsis :}

To clarify the bubble evolution during firing of one coat porcelain enamels on cold rolled Ti bearing steel sheets produced by continuous casting, analysis of gas chromatography and mass spectrometer of gas collected from the enamel on three kinds of enamelling steel sheets were analysed, and microstructures of both pickled specimens and fired ones were examined precisely. It was found that gases of one coat enamelling on $\mathrm{Ti}$ bearing steel sheet consisted of about $53 \%$ of hydrogen and $46 \%$ of nitrogen. The results show that hydrogen is thought to evolve from the water-iron reaction during firing, and nitrogen is thought to come from the air trapped in etched dent of grain boundary on steel sheet surface and between frit particles.

On the other hand, gases of capped steel sheet and less-Al-high-oxygen steel sheet produced by continuous casting consisted of $10 \%$ nitrogen and $90 \%$ of hydrogen which is thought to evolve from the same reaction as before.

Key words : porcelain enamel; enamelling steel sheet; one coat enamelling; bubble; gas analysis; gas chromatography ; mass spectrometer; ingot making ; continuous casting; low carbon steel ; plate.

\section{1. 緒言}

現在，連続鋳造のほうろう用冷延鋼板は，極低炭素高 酸素鋼板， $\mathrm{Ti}$ 添加鋼板（以下 $\mathrm{CC}-\mathrm{Hi}[\mathrm{O}]$ 鋼板, $\mathrm{CC}-\mathrm{Ti}$ 添加鋼板と記す) および B 添加鋼板などがある. 両面一回掛け用として開発された CC-Hi〔O〕鋼板は, 深絞り性に難点があり, その向上に努めている. 一方, CC-Ti 添加鋼板は, 深絞り性は極めて良好であるが, 耐泡性に難点があり，とくに，ピンホールは鋳型鋳造の キャップド鋼板（以下 IC-Cap 鋼板と記す）よりやや多 いので両面一回掛け用には適用しにくく，抒もに，二回 掛け用に使用されている。 そこで，加工性，ほうろう性 が優れ, かつ, 両面一回掛けが叮能な鋼板の製造が必要 である。

これまで, ほうろうの泡原因は, 硫酸酸洗時に発生し たスマット ${ }^{1)}$ または炭化物 ${ }^{2)}$ が焼成時に分解したものと 推定されている。 さらに, CC-Ti 添加鋼板については, 硫酸酸洗時に結晶粒界が選択腐食されて堆積したスマッ ド)によるものであると推定されている．一方，ほうろ う層の泡中ガスを分析した報告 ${ }^{4) ６)}$ はあるが，それら は下釉または下釉と上釉の二回掛けでの泡ガスであり， いずれも下釉掛けがベースの報告が多い.
さらに，泡中のガス成分のうち $\mathrm{H}_{2}$ と $\mathrm{N}_{2}$ または $\mathrm{H}_{2}$ と $\mathrm{CO}_{x}$ を主体に分析したものが多く，他の成分が不明 確である。また，連鋳鋼での研究報告もない.

一方, 質量分析では質量数 28 の $\mathrm{CO}$ と $\mathrm{N}_{2}$ を分離し にくいので，あらかじめガスクロマトグラフィーで CO と $\mathrm{N}_{2}$ のおおよその比率を分析する必要がある.

本研究は, CC-Ti 添加鋼板に重点をおき, 高酸素系 の 2 鋼種と対比させながら, 两面淔接一回掛けほうろう での泡ガス発生機構の究明をはかったものである.

\section{2. 実 験 方 法}

（1）供試材: Table 1 に示す板厚 $0.8 \mathrm{~mm}$ の新日本製 鉄(株)製冷延鋼板を Fig. 1 に示す両面直接一回掛けほ うろう処理工程で調製した。 Table 2 に直接一回掛け釉 薬の配合割合を示す。ここで CC-Ti 添加鋼极について は，酸洗時間の影響を調査するため酸洗時間 $15 \mathrm{~min}$ ついても調査した。また，泡から採取したガス量を多く するため，ほうろう厚みを $500 \mu \mathrm{m}$ （通常 $100 \mu \mathrm{m} ）$ と厚 めにした，とくに，ガスクロマトグラフィーでは，ガス 量が少ないと思われる IC-Cap および CC-Hi〔O] 鋼板 は $0.8 t \times 20 w \times 150 l \cdot(\mathrm{mm})$ の試料で 45 枚, CC-Ti 添加鋼板は 25 枚作成した。

昭和 63 年 11 月本会講演大会にて発表 平成元年 1 月 9 日受付 (Received Jan. 9, 1989)

* 新日本製鉄(株)薄板研究センター（Sheet \& Coil Research Lab., Nippon Steel Corp., 5-10-1 Fuchinobe Sagamihara 229)

*2 日鉄テクノリサーチ(株)研究第一部（Research Lab.-1, NIPPON STEEL TECHINO RESEARCH Ltd.) 
Table 1. Chemical composition of steel sheets used (wt \%).

\begin{tabular}{l|cccccccccccc}
\hline \multicolumn{1}{c|}{ Steel } & $\mathrm{C}$ & $\mathrm{Si}$ & $\mathrm{Mn}$ & $\mathrm{P}$ & $\mathrm{S}$ & $\mathrm{Al}$ & $\mathrm{Cu}$ & $\mathrm{Ti}$ & $\mathrm{O}$ \\
\hline IC-Cap & 0.0019 & 0.006 & 0.36 & 0.010 & 0.008 & 0.007 & 0.026 & - & 0.0619 & 0.0025 \\
CC-Hi [O\} & 0.0035 & 0.004 & 0.21 & 0.014 & 0.014 & 0.002 & 0.030 & - & 0.0461 & 0.0018 \\
CC-Ti-bearing & 0.0023 & 0.021 & 0.21 & 0.006 & 0.027 & 0.066 & 0.030 & 0.090 & 0.0051 & 0.0027 \\
\hline
\end{tabular}

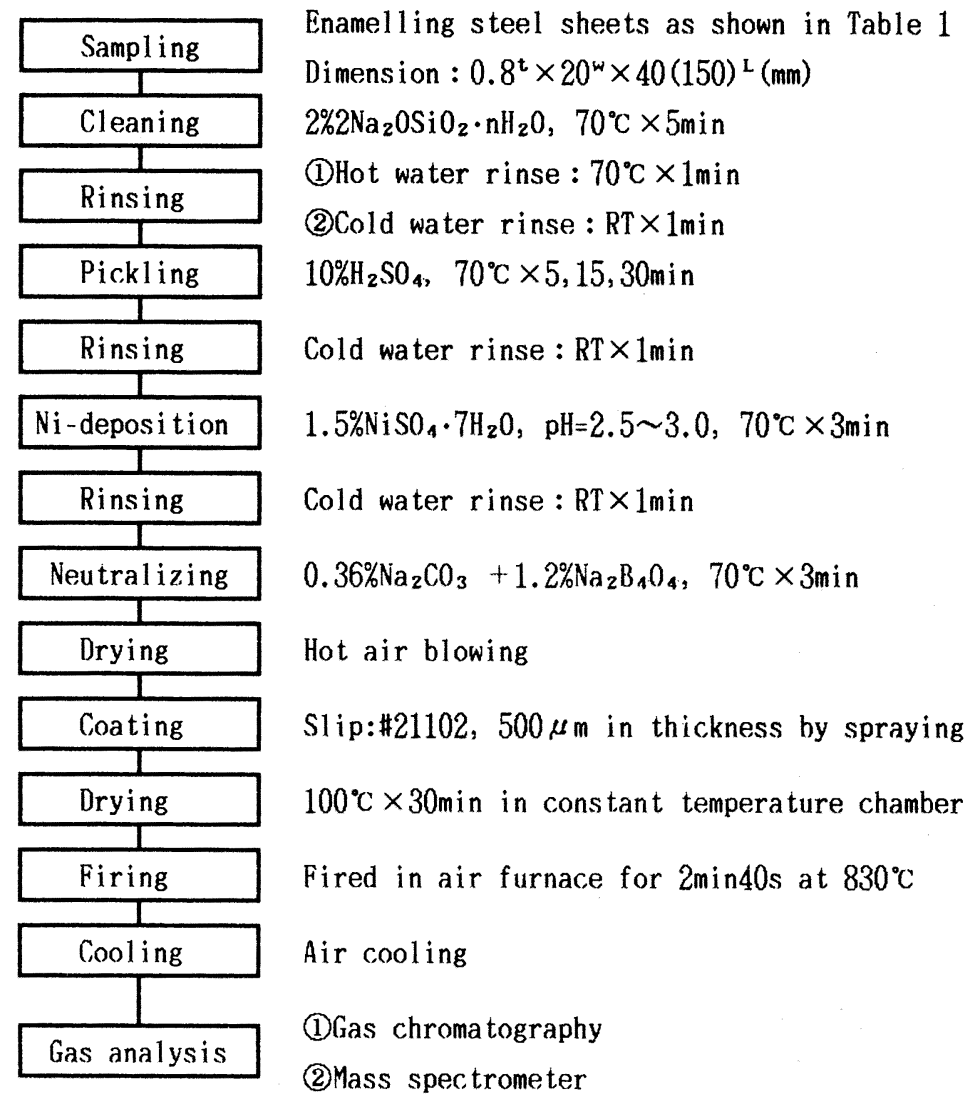

Fig. 1. Experimental procedure of one coat enamelling and gas analysis in enamels.

Table 2. Composition of \#21102 enamel.

\begin{tabular}{l|c}
\hline \multicolumn{1}{c|}{ Ingredient } & Parts by weight \\
\hline Frit 1553-B & 100 \\
Clay & 6 \\
Magnesium carbonate & 0.2 \\
Sodium nitrite & 0.25 \\
Water & 45 \\
\hline
\end{tabular}

( 2 )泡ガス分析 : (1)Fig. 2 に示すように, 飽和食塩水 (50vol\%)-グリセリン (50 vol\%) 溶液 ${ }^{4) 5)}$ (常温, 約 91) 中で，供試材の両端を㨝じり，ほうろう層を破砕した。 この時ほうろう層から放出されるガスをガラス製ガス捕 集器で採取し, マイクロシリンジに分取後, ガスクロマ 卜分析装置（島津製作所製 GC-6 AM）で分析した。

分析条件は, カラムはモレキュラーシーブ $5 \mathrm{~A}$ で,
温度 $80^{\circ} \mathrm{C}$, 検出器は熱伝導度検出器で, 温度 $100^{\circ} \mathrm{C} お$ よびキャリヤーガスは Heで, 流量 $80 \mathrm{ml} / \mathrm{min}$ である.

(2)ブローホールガス抽出装置内にほうろう材を固定 し, 真空中 $\left(1 \times 10^{-7}\right.$ Torr $)$ でほうろう層をドリルで 切削し $(4 \mathrm{~mm} \phi, 60 \mathrm{rpm})$ ，この時ほうろう層から放出 されるガス成分の質量スペクトルを質量分析計 (日電ア ネルバ製四重極質量分析計 515 B 型）で測定した。こ こで, ほうろう鋼板を切削前の装置内部の残留ガス成分 をバックグラウンドとし，質量分析計の掃引時間 $=1 \mathrm{~s}$, 測定感度 $=1 \times 10^{-12} \mathrm{~A}$, エミッション電流 $=1.0 \mathrm{~mA}$, ガス抽出後測定開始までの時間 $=0.3 \mathrm{~s}$, 分解能 1 で測 定した.

( 3 ) ほうろう用鋼板の硫酸酸洗およびほうろう後の断 
Table 3. Gases contained in the bubbles analysed by using gas chromatography.

\begin{tabular}{|c|c|c|c|c|c|c|c|c|c|c|}
\hline \multirow{2}{*}{ Steel } & \multirow{2}{*}{$\underset{(\mu \mathrm{m})}{t_{E}}$} & \multirow{2}{*}{$n$} & \multirow{2}{*}{$\underset{(\mathrm{ml})}{V}$} & \multirow{2}{*}{$\begin{array}{c}V_{a} \\
(\mathrm{ml})\end{array}$} & \multicolumn{4}{|c|}{ Intensity of peak ${ }^{*}$} & \multicolumn{2}{|c|}{ Composition $^{* *}$} \\
\hline & & & & & $\mathrm{H}_{2}$ & $\mathrm{~N}_{2}$ & $\mathrm{CO}$ & $\mathrm{O}_{2}$ & $\mathrm{~N}_{2}$ & $\mathrm{CO}$ \\
\hline IC-Cap & 373 & 45 & $\sim 0.1$ & 0.1 & $(3.0)$ & $(975)$ & 0 & 178 & 100 & 0 \\
\hline $\mathrm{CC}-\mathrm{Hi}[\mathrm{O}]$ & 338 & 45 & $\sim 0.1$ & 0.07 & $(2.0)$ & 811 & 0 & 142 & 1.00 & 0 \\
\hline $\mathrm{CC}-\mathrm{Ti}^{- \text {bearing }}$ & 373 & 25 & 1.5 & $\begin{array}{l}0.1 \\
0.2\end{array}$ & $\begin{array}{r}7.7 \\
16.4\end{array}$ & $\begin{array}{r}687 \\
1176\end{array}$ & $\begin{array}{l}0 \\
0\end{array}$ & $\begin{array}{l}149 \\
276\end{array}$ & $\begin{array}{l}100 \\
100\end{array}$ & $\begin{array}{l}0 \\
0\end{array}$ \\
\hline $\mathrm{CC}-\mathrm{Ti}$-bearing & 454 & 24 & 1.5 & $\begin{array}{l}0.1 \\
0.2\end{array}$ & $\begin{array}{l}3.9 \\
7.0\end{array}$ & $\begin{array}{l}272 \\
511\end{array}$ & $\begin{array}{l}0 \\
0\end{array}$ & $\begin{array}{r}37 \\
108\end{array}$ & $\begin{array}{l}100 \\
100\end{array}$ & $\begin{array}{l}0 \\
0\end{array}$ \\
\hline
\end{tabular}

$t_{E}:$ Thickness of enamels $n:$ Nunber of specimens

$V$ : Total volume of gas taken from the enamels $V_{a}$ : Gas volume for analysis

* Intensity of peak: Calculated value of peak area in $\mathrm{mm}^{2}$

( ); Approximation value

** Composition : Relative composition of $\mathrm{N}_{2}$ and $\mathrm{CO}$ in vol\%

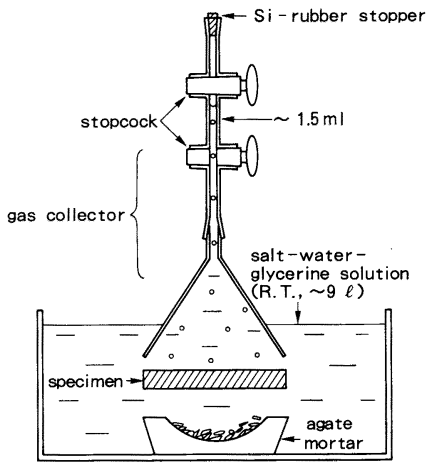

Fig. 2. Schematic drawing of apparatus for gas collection unit.

面検鏡 : 上記ほうろう処理工程で酸洗材（酸洗時間 1 , 5 および $30 \mathrm{~min}$ ) とほうろう材を作成し，樹脂に埋め 込み，C断面を\#120〜 \#1500ペーパーで粗研磨し， $\mathrm{Al}_{2} \mathrm{O}_{3}$ で什上研磨後検鏡した。

\section{3. 実 験 結 果}

\section{$3 \cdot 1$ 採取ガス量}

酸洗時間が 5 min の試料について，ほうろう層から採 取した泡中ガス量を泡中ガス量/ほうろう体積で表示す ると, (1 ) IC-Cap おょび CC-Hi〔O] 鋼板では約 0.1 $\mathrm{ml} / 90 \mathrm{~cm}^{3}$ である. (2) CC-Ti 添加鋼板では約 1.5 $\mathrm{ml} / 52 \mathrm{~cm}^{3}$ で, 上記の 2 鋼種に比べガス量が約 26 倍も 多い.

\section{$3 \cdot 2$ ガス組成}

(1) ガスクロマトグラフィーによる泡中ガスの分析 :

Fig. 3 および Table 3 に，ほうろう層から採取した泡 中ガスをガスクロマトグラフィーで分析した結果を示 す. (1)ほうろう層から採取したガスには， $\mathrm{H}_{2}, \mathrm{~N}_{2}$ およ び $\mathrm{O}_{2}$ か $\mathrm{Ar}$ が存在するが， $\mathrm{CO}$ は存在しない。また，

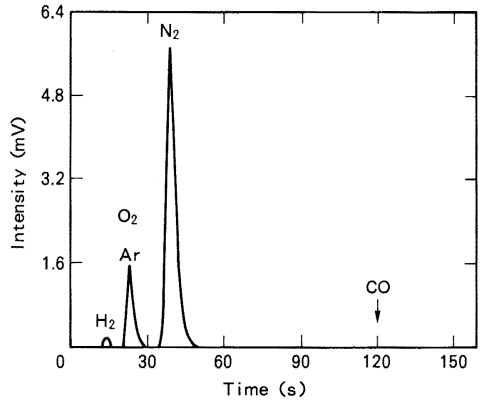

Fig. 3. Chromatogram of gases taken from the enamel on $\mathrm{CC}-\mathrm{Ti}$-bearing steel sheets.

$\mathrm{Ar}$ と $\mathrm{O}_{2}$ のピークと重なっており，分離できなかった。 したがって，質量数 $28\left(\mathrm{~N}_{2}, \mathrm{CO}\right)$ は, $\mathrm{N}_{2}$ が主成分で ある. (2) $\mathrm{H}_{2}$ はキャリヤーガス（He）との熱伝導度の差 が小さいため, 検出感度がきわめて低く, かつ, $\mathrm{H}_{2}$ 量 が約 $0.25 \mathrm{ml}$ 以下ではピークの異常反転7)が発生したた め，相対感度係数の測定ができず，ガスクロマトグラ フィーによる泡中ガス組成の定量分析は困難である.

( 2 ) 質量分析法による泡中ガスの分析 : Fig. 4 および Table 4 にほうろう層から抽出したガスの質量分析結果 を示す。この質量分析結果と先のガスクロマトグラ フィーの結果から，(1)ほうろう層の泡中ガスは $\mathrm{H}_{2}$ およ び $\mathrm{N}_{2}$ が主体で， $\mathrm{CO}_{2}, \mathrm{Ar}$ および $\mathrm{O}_{2}$ も微量（約 $0.5 \%$ 以下) 存在する. (2)IC-Cap および CC-Hi〔O]鋼板の 泡中ガスは $\mathrm{H}_{2}$ が主成分（約 $90 \%$ ）で， $\mathrm{N}_{2}$ もそれぞれ 約 12 および $7 \%$ 存在する. (3)CC-Ti 添加鋼板は $\mathrm{N}_{2}$ が 約 $46 \%$ と多く, $\mathrm{H}_{2}$ は約 $53 \%$ に減少している. 酸洗時 間を長くすると（5 $\rightarrow 15 \mathrm{~min} ）, \mathrm{~N}_{2}$ がさらに増加する. また, 質量分析強度から考えて, CC-Ti 添加鋼板のガ ス量は他鋼種に比べ $\mathrm{H}_{2}$ はほほ同量, $\mathrm{N}_{2}, \mathrm{Ar}$ および $\mathrm{O}_{2}$ は約 8〜15 倍, $\mathrm{CO}_{2}$ は約 2 3 倍多い. 


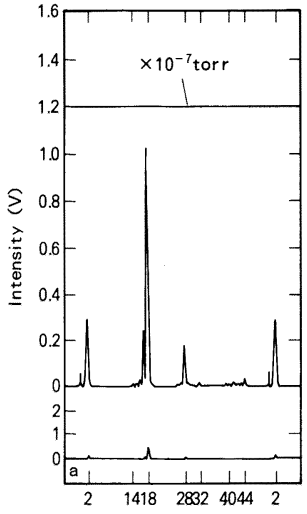

a) back ground

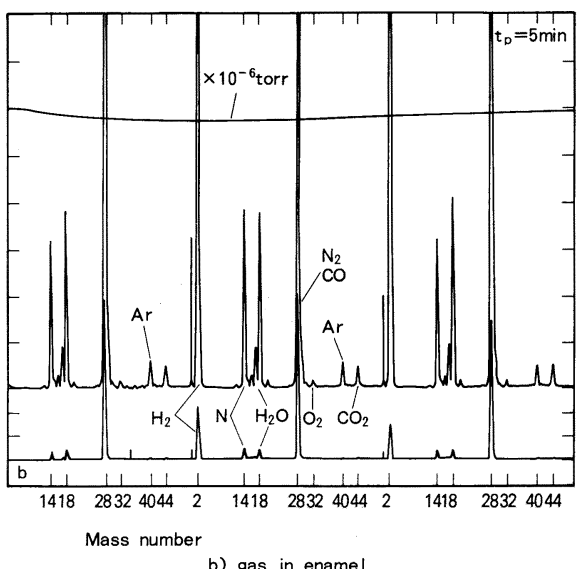

b) gas in ename
Fig. 4. Mass spectrum of gases in enamel on $\mathrm{CC}$-Ti-bearing steel sheets.

Table 4. Gases contained in the bubbles analysed by using mass spectrometer.

\begin{tabular}{|c|c|c|c|c|c|c|c|c|c|}
\hline \multirow{2}{*}{\multicolumn{2}{|c|}{$\begin{array}{l}\text { Mass and } \\
\text { composition }\end{array}$}} & \multicolumn{4}{|c|}{ Intensity $(\mathrm{mV})$} & \multicolumn{4}{|c|}{ Composition (vol\%) } \\
\hline & & \multirow{2}{*}{$\frac{\text { IC-Cap }}{4950}$} & \multirow{2}{*}{$\frac{\mathrm{CC}-\mathrm{Hi}[\mathrm{O}]}{5045}$} & \multicolumn{2}{|c|}{$\mathrm{CC}-\mathrm{Ti}$-bearing } & \multirow{3}{*}{$\begin{array}{c}\text { IC-Cap } \\
\underline{87.6}\end{array}$} & \multirow{2}{*}{$\frac{\mathrm{CC}-\mathrm{Hi}[\mathrm{O}]}{\underline{92.5}}$} & \multicolumn{2}{|c|}{$\mathrm{CC}-\mathrm{Ti}^{-}$-bearing } \\
\hline 2 & $\underline{\mathrm{H}_{2}}$ & & & 6163 & 5138 & & & $\underline{52.5}$ & 42.4 \\
\hline (12) & (C) & 2 & 2 & 1 & 4 & & & & \\
\hline (14) & (N) & 40 & 20 & 246 & 375 & & & & \\
\hline 18 & $\mathrm{H}_{2} \mathrm{O}$ & 0 & 0 & 0 & 0 & 0 & 0 & 0 & 0 \\
\hline (20) & $\mathrm{Ne},(\mathrm{Ar})$ & 2 & 1 & 11 & 11 & $<0.1$ & $<0.1$ & 0.1 & 0.1 \\
\hline 28 & $\mathrm{~N}_{2}, \mathrm{CO}$ & 670 & 372 & 5415 & 6910 & 11.9 & 6.8 & 46.2 & 57.0 \\
\hline 30 & $\mathrm{NO},\left(\mathrm{CO}, \mathrm{CO}_{2}\right)$ & 3 & 1 & 36 & 9 & $<0.1$ & $<0.1$ & $\frac{0.3}{0.3}$ & $<0.1$ \\
\hline 32 & $\mathrm{O}_{2}$ & 2 & 2 & 15 & 2 & $<0.1$ & $<0.1$ & 0.1 & $<0.1$ \\
\hline 40 & $\mathrm{Ar}$ & 9 & 4 & 60 & $\underline{46}$ & 0.2 & $<0.1$ & 0.5 & 0.4 \\
\hline 44 & $\mathrm{CO}_{2}$ & 14 & 29 & $\overline{41}$ & $\overline{20}$ & 0.2 & 0.5 & 0.3 & 0.2 \\
\hline 64 & $\mathrm{SO}_{2}$ & 0 & 0 & 0 & 0 & 0 & 0 & 0 & 0 \\
\hline \multicolumn{2}{|r|}{ Total } & 5648 & 5453 & 11730 & 12125 & 100.1 & 99.9 & 100.0 & 100.1 \\
\hline \multicolumn{2}{|c|}{ Pickling time (min) } & 5 & 5 & 5 & 15 & 5 & 5 & 5 & 15 \\
\hline \multicolumn{2}{|c|}{ Thickness ( $\mu \mathrm{m})$} & 625 & 570 & 535 & 463 & 625 & 570 & 535 & 463 \\
\hline
\end{tabular}

( ) : Fragment peak

\section{$3 \cdot 3$ 硫酸酸洗およびほうろう後の断面組織}

Photo. 1〜2に $10 \%$ 硫酸酸洗 (浴温 $70^{\circ} \mathrm{C}, 1 \sim 30 \mathrm{~min}$ ) 後およびほうろうの断面組織を示す。これらの結果から (1)IC-Cap および CC-Hi〔O〕鋼板は, 酸洗で表面粗度 は大きくなるが, 結昆粒界が浸食されている様相はみら れない. (2)一方, CC-Ti 添加鋼板は, 酸洗でとくに結 晶粒界が選択腐食され，腐食幅および深さは酸洗時間が $5 \mathrm{~min}$ でそれぞれ約 $3 \mu \mathrm{m}$ および $6 \mu \mathrm{m}$, 酸洗時間が 30 min では約 $10 \mu \mathrm{m}$ および $15 \mu \mathrm{m}$ にもなる. (3)さらに, $\mathrm{CC}-\mathrm{Ti}$ 添加鋼板のほうろう層の泡は他鋼種に比べほう ろう/地鉄界面に多い.

\section{4. 考察}

\section{$4 \cdot 1$ 泡中ガス量}

CC-Ti 添加鋼板は，他鋼種に比べてほうろう層の泡 中ガス量が約 26 倍も多い.この原因は, Photo. 2 に示 すように，IC-Cap および CC-Hi [O] 鋼板のほうろう
層には, 直径約 $25 \mu \mathrm{m}$ 以下の泡が $200 \sim 300$ 個 $/ \mathrm{mm}^{2}$ 存 在するが, CC-Ti 添加鋼板では, 泡数が多く（400 個 $\left./ \mathrm{mm}^{2}\right)$ ，しかも，直径 $20 \sim 80 \mu \mathrm{m}$ の大きい泡が多いた めと考えられる.

また，同材は，硫酸酸洗時に結晶粒界が優先腐食され やすく，この部分にトラップされた空気が泡の主原因と 考えられるが, 後述の $\mathrm{N}_{2}, \mathrm{O}_{2}$ および $\mathrm{Ar}$ ガスの生成機 構でさらに詳細に考察する.

\section{$4 \cdot 2 \mathrm{CO}$ および $\mathrm{N}_{2}$ の組成計算}

今回ガスクロマトグラフィーで測定したほうろう層の 泡中ガスは，CO がいずれの鋼種からも極微量ないしは 検出されなかった。しかし，この測定方法では全体のガ スの定量分析が困難なため, 質量数 28 の $\mathrm{CO}$ と $\mathrm{N}_{2}$ の 組成を以下の計算で求めた.

(1) 質量数の 12 の質量分析強度による組成計算

質量数 28 および 12 の強度は式( 1 ) および $(2)$ に示 すぺアレントピークとフラグメントピークの和で表され 

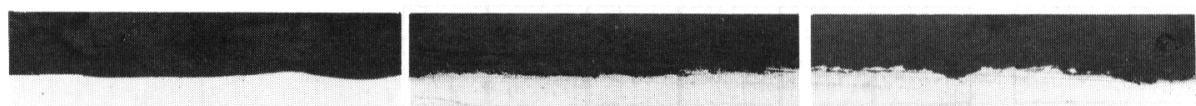

a

b
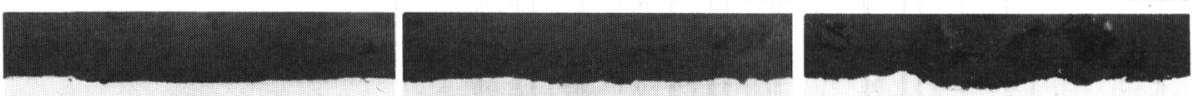

d

e

f
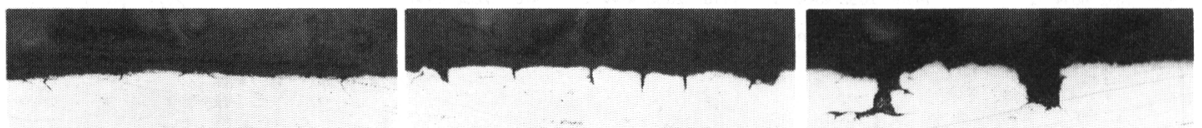

h

$i^{*}$

$20 \mu \mathrm{m}$

a)b)c) IC-Cap

a)d)g) $t_{p}=1 \mathrm{~min}$

d)e)f) $\mathrm{CC}-\mathrm{Hi}(\mathrm{O}$

b)e)h) $t_{p}=5 \mathrm{~min}$

g)h)i) CC-Ti-bearing

c)f)i) $t_{p}=30 \mathrm{~min}$

Photo. 1. Optical micrographs of subsurface of enamelling steel sheets after pickling at $70^{\circ} \mathrm{C}$ in $10 \% \mathrm{H}_{2} \mathrm{SO}_{4}$ solution.
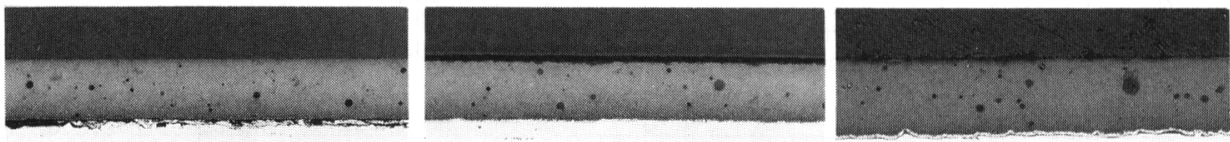

a

b
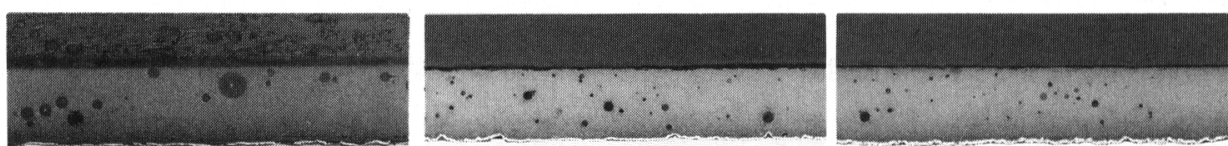

d

e
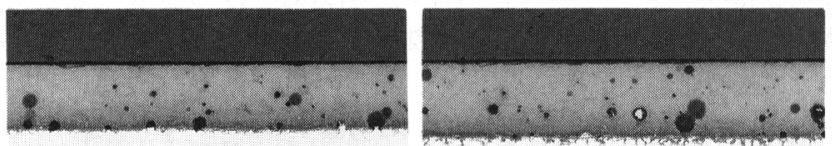

f

g

h

i

$100 \mu \pi$

a)b)c) IC-Cap d)e)f) $\mathrm{CC}-\mathrm{Hi}(\mathrm{O} \quad$ g)h i) $\mathrm{CC}-\mathrm{Ti}$-bearing

$\begin{array}{lll}\text { a)d)g) } t_{p}=5 \mathrm{~min} & \text { b)e)h) } t_{p}=15 \mathrm{~min} & \text { c)f)i) } t_{p}=30 \mathrm{~min}\end{array}$

Photo. 2. Optical micrographs of one coat enamelled steel sheets after pickling at $70^{\circ} \mathrm{C}$ in $10 \% \mathrm{H}_{2} \mathrm{SO}_{4}$ solution.

る.

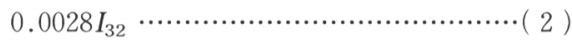

$I_{28}=I_{\mathrm{CO}}+I_{\mathrm{N}_{2}}+0.1973\left(I_{44}-0.0215 I_{32}\right) \cdots \cdots(1)$

ここで, $I_{28}, I_{44}, I_{32}$ および $I_{12}$ は Table 4 の質量数

$I_{12}=0.0438 I_{\mathrm{CO}}+0.0762\left(I_{44}-0.0215 I_{32}\right)+$

$28,44,32$ および 12 の強度 $(\mathrm{mV}), I_{\mathrm{CO}}$ および $I_{\mathrm{N}_{2}}$ は 
Table 5. Pattern coefficient of standard gases.

\begin{tabular}{c|c|c|c|c}
\hline Mass & $\mathrm{N}_{2}$ & $\mathrm{CO}$ & $\mathrm{CO}_{2}$ & $\mathrm{O}_{2}$ \\
\hline 12 & & 4.38 & 7.62 & 0.28 \\
14 & 8.30 & 0.59 & 19.73 & \\
28 & 100 & 100 & 100 & 2.15 \\
32 & & & 100 & 2.5 \\
44 & & &
\end{tabular}

Table 6. Gases contained in the bubbles.

\begin{tabular}{l|c|c|c|c|c|c|c}
\hline \multirow{2}{*}{ Steel } & \multirow{2}{*}{$\begin{array}{c}t_{p} \\
(\mathrm{~min})\end{array}$} & \multicolumn{6}{|c}{ Composition (vol\%) } \\
\cline { 3 - 8 } & & $\mathrm{H}_{2}$ & $\mathrm{~N}_{2}$ & \multicolumn{1}{c|}{$\mathrm{CO}$} & \multicolumn{1}{c}{$\mathrm{O}_{2}$} & $\mathrm{Ar}$ & $\mathrm{CO}_{2}$ \\
\hline IC-Cap & 5 & 87.6 & 11.5 & 0.4 & $<0.1$ & 0.2 & 0.2 \\
\hline CC-Hi [O] & 5 & 92.5 & 6.8 & 0 & $<0.1$ & $<0.1$ & 0.5 \\
\hline CC-Ti-bearing & 5 & 52.5 & 46.2 & 0 & 0.1 & 0.5 & 0.3 \\
& 15 & 42.4 & 56.5 & 0.5 & $<0.1$ & 0.4 & 0.2 \\
\hline
\end{tabular}

$t_{p}$ : Pickling time at $70^{\circ} \mathrm{C}$ in $10 \% \mathrm{H}_{2} \mathrm{SO}_{4}$ solution

質量数 28 の $\mathrm{CO}$ および $\mathrm{N}_{2}$ の強度 $(\mathrm{mV}), 0.1973$ と $0.0762 ， 0.0438$ および 0.0215 と 0.0028 はそれぞれ Table 5 の $\mathrm{CO}_{2}, \mathrm{CO}$ および $\mathrm{O}_{2}$ ガスの)パターン係数 (ペ アレントピークの強度を 100 とした時のフラグメント ピークの強度比）の $1 / 100$ である.

この計算結果を Table 6 に示す. 式( 1 ), ( 2 )から, 質量数 $28\left(\mathrm{CO}, \mathrm{N}_{2}\right)$ の組成は, $\mathrm{N}_{2}$ が主成分で, $\mathrm{CO}$ は約 $3 \%$ 以下（全体のガスの約 $0.5 \%$ 以下）の微量で ある.この結果はガスクロマトグラフィーの測定結果に 近い。また，計算結果から得られた泡中ガス組成の $\mathrm{N}_{2}$ は, $\operatorname{Ar} の$ 約 50 100 倍の割合で存在しており, 空気の 組成比 $\left(\mathrm{N}_{2} / \mathrm{Ar}=83.8\right)$ にほぼ近い值である.

( 2 )質量数 14 の質量分析強度による組成計算

同様に, 式( 1 )および質量数 14 の強度比( 3 )から質 量数 $28\left(\mathrm{CO}, \mathrm{N}_{2}\right)$ の組成を計算すると, $\mathrm{CO}$ が約 30〜 $50 \%$ も存在する.

$I_{14}=0.0059 I_{\mathrm{CO}}+0.0830 I_{\mathrm{N}_{2}}$

ここで， $I_{14}$ は質量数 14 の強度 $(\mathrm{mV}), 0.0059$ およ び 0.0830 は CO および $\mathrm{N}_{2}$ ガスの質量数 14 のフラグ メントピークのパターン係数の $1 / 100$ である.

この結果は, Table 4 に示した 3 鋼種の質量数 12 の 強度は小さく, かつ, 供試材の炭素量はきわめて少ない ので, $\mathrm{CO}$ が約 30〜 $50 \%$ も存在するとは考えられない. また, 質量数 14 の強度は 28 の強度变化とよく対応し ている.

以上の理由から, 質量数 28 は $\mathrm{N}_{2}$ が主成分で $\mathrm{CO}$ は ほとんど存在していないと考えられる. 本項の計算結果 が実測值と大幅に異なった理由として, 泡中ガスでは質 量数 14 のパターン係数が小さくなっていることが考え られる.すなわち, 泡中ガスの質量数 14 および 28 の 強度から質量数 14 のパターン係数を求めると平均 5.39
となり， $\mathrm{H}_{2}$ と $\mathrm{N}_{2}$ が主成分である泡中ガスでは，Table 5 の $\mathrm{N}_{2}$ ガスのパターン係数に比べて小さくなってい る. この原因は, 分析時のガスの圧力および組成の影響 によるものと考えられる。この值を用いて式( 1 )および (3)で $\mathrm{CO}$ と $\mathrm{N}_{2}$ の組成比を計算すると質量数 12 の強 度で計算した結果とほぼ一致する。したがって， $\mathrm{N}_{2}$ の パターン係数を 5.39 に補正する方がよいと考えられ る.

以上の結果から，(1)ほうろう層の泡中ガスは， $\mathrm{H}_{2}$ お よび $\mathrm{N}_{2}$ が主成分で $\mathrm{CO}, \mathrm{CO}_{2}, \mathrm{Ar}$ および $\mathrm{O}_{2}$ も微量存 在する. (2) IC-Cap および CC-Hi $[\mathrm{O}]$ 鋼板は, $\mathrm{H}_{2}$ が 主成分 (約 $90 \%$ ) で, $\mathrm{N}_{2}$ は約 $10 \%$ である. (3)CC- $\mathrm{Ti}$ 添加鋼板は $\mathrm{N}_{2}$ が約 $46 \%$ も存在し， $\mathrm{H}_{2}$ は $53 \%$ である ことが明らかになった。

\section{$4 \cdot 3$ ほうろう層の泡中ガスの生成機構}

ほうろう層の泡中ガス成分は $\mathrm{H}_{2}, \mathrm{~N}_{2}, \mathrm{CO}_{2}, \mathrm{Ar}$, $\mathrm{CO}$ および $\mathrm{O}_{2}$ である.これらのガスの生成機構につい て考察する.

( 1 ) $\mathrm{H}_{2}$ ガスの生成機構: ほうろうの爪とびは $\mathrm{H}_{2}$ ガ

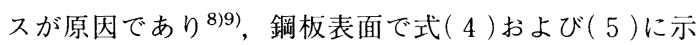
す反伈により発生する。 さらに， $\mathrm{H}_{2}$ の発生源と寄与率 はフリット中の水 $50 \%$, 焼成炉中の水 $43 \%$ である ${ }^{10)}$.

$$
x \mathrm{Fe}+y \mathrm{H}_{2} \mathrm{O} \rightarrow \mathrm{Fe}_{x} \mathrm{O}_{y}+2 y[\mathrm{H}]
$$$$
[\mathrm{C}]+\mathrm{H}_{2} \mathrm{O} \rightarrow \mathrm{CO}+2[\mathrm{H}]
$$

ここで,〔C〕は鋼中固溶炭素（カーバイドも含む） および〔H]は発生期の原子状水素である.

IC-Cap および CC-Hi $[\mathrm{O}]$ 鋼板の泡中ガスも $\mathrm{H}_{2}$ が 主成分であり，上の反応式( 4 )が主反応と考えられる.

これに反し, CC-Ti 添加鋼板の泡中ガスは $\mathrm{H}_{2}$ が約 $53 \%$ で，その他のガスの生成機構が重要である.

$\mathrm{CHU}$ ら $^{6)}$ の泡中ガスの化学分析結果では $\mathrm{H}_{2}$ は約 $90 \%, \mathrm{~N}_{2}$ は約 $10 \%$ である.これらの值は本研究の IC-Cap および CC-Hi [O $]$ 鋼板の結果に近いが, 鋼種, 鋼成分が不明で, $\mathrm{N}_{2}$ はほうろう表面および捕集容器の 内壁に吸着した空気，あるいは分析機器のリークにより 污染されたものであるとしている.

一方，MOORE ら ${ }^{5)}$ は IC 材 (C: 0.012\%) で下釉を焼 成時の泡中ガスを質量分析し，焼成初期には $\mathrm{CO}_{x}$ の発 生が多く，通常および過焼成では $\mathrm{H}_{2}$ が多くなると報告 している．この結果は焼成時のガス発生を時系列的に測 定した点で注目するに值するが，下釉での泡中ガスであ り，かつ，質量分析のみで空気 $\left(\mathrm{N}_{2}\right.$ など）成分を無視 している点と同じ質量数の $\mathrm{CO}$ と $\mathrm{N}_{2}$ との分離, 定量し ているかが不明な点が問題である.

( 2 ) $\mathrm{N}_{2}, \mathrm{O}_{2}$ および $\mathrm{Ar}$ ガスの生成機構 : IC-Cap お 


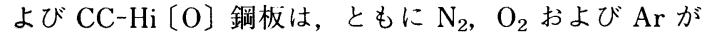
合計で約 $10 \%$ 存在する。これらのガスは空気成分と考 えられるが， $\mathrm{O}_{2}$ は空気の組成に比べて少ないのは, 式 (6)に示す鋼板表面との酸化反応掞よび式 $(7)$ （9)に 示す釉薬が溶融する前の $500 \sim 600^{\circ} \mathrm{C}$ での酸洗スマット の [C] との反㐫で $\mathrm{CO}$ ガスが発生し, これが釉薬中の 表面に移動する間に酸化して $\mathrm{CO}_{2}$ ガスとなって大気中

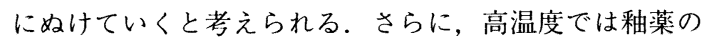
酸化にも消費されたものと考えられる.

$$
\begin{aligned}
& x \mathrm{Fe}+1 / 2 y \cdot \mathrm{O}_{2} \rightarrow \mathrm{Fe}_{x} \mathrm{O}_{y} \\
& 3[\mathrm{C}]+2 \mathrm{O}_{2} \rightarrow 2 \mathrm{CO}+\mathrm{CO}_{2} \\
& 3[\mathrm{C}]+4 \mathrm{H}_{2} \mathrm{O} \rightarrow 2 \mathrm{CO}+\mathrm{CO}_{2}+8[\mathrm{H}]
\end{aligned}
$$

一般に, ほうろう釉薬を施釉し, 乾燥後釉薬粒子 (平 均粒径約 $25 \mu \mathrm{m}$ ）間のすきまに空気が侵入しており，焼 成時に残存したものと考えられる。参考までに空気の組 成 (vol\%) を示すと, $\mathrm{N}_{2}: 78, \mathrm{O}_{2}: 21, \mathrm{H}_{2} \mathrm{O}: 1 \sim 2.8, \mathrm{Ar}$ ： $0.93, \mathrm{CO}_{2}: 0.032, \mathrm{Ne}: 0.0018$ および $\mathrm{CO}: 0.000012$ である ${ }^{11)}$.

一方, CC- $\mathrm{Ti}$ 添加鋼板の泡中ガスの $\mathrm{N}_{2}$ は約 $46 \%$ で, $\mathrm{N}_{2}$ および $\mathrm{Ar}$ ガス量から考えて空気が約 $60 \%$ 存在し ているようである。この鋼板のほうろう工程での泡ガス 発生機構を Fig. 5 に示す。すなわち，鋼板を $10 \%$ 硫 酸液中で, $70^{\circ} \mathrm{C}, 5 \mathrm{~min}$ 酸洗すると結晶粒界が優先腐食 され ${ }^{3}$ ，腐食幅が約 $3 \mu \mathrm{m}$ ，深さは約 $6 \mu \mathrm{m}$ にもなる。さ らに, 施釉時には, 平均粒径約 $25 \mu \mathrm{m}$ の釉薬が前記粒 界腐食溝に侵入できず空気をトラップしたまま焼成さ れ，ほうろう層に空気と式(4)の反応で発生した $\mathrm{H}_{2}$ と を主成分とする泡になったものと推定される. 空気の起 源についてさらに詳細に検討すると，この内，約 30\% の空気は鋼板の結晶粒界の腐食溝の体積および残りの約 $30 \%$ はフリット粒子間の空隙の体積にそれぞれ相当し， ここにトラップしていた空気の一部と考えられる。これ は IC-Cap 鋼板で測定された泡ガス中の $\mathrm{N}_{2}$ は約 $12 \%$,

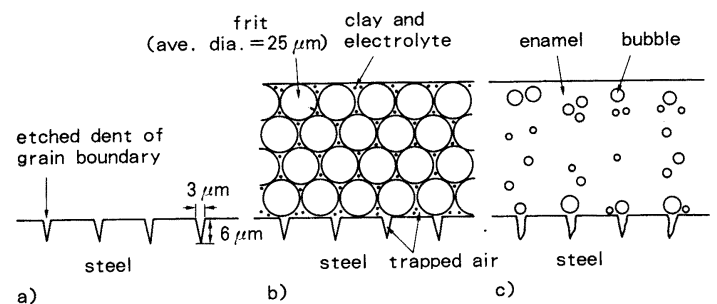

a) After pickling b) After coating and drying c) After firing Fig. 5. Schematic representation of mechanism for the evolution of bubble under one coat enamelling process on $\mathrm{CC}-\mathrm{Ti}$-bearing steel sheet.
空気に換算すると約 $15 \%$ に比べて約 2 倍も多い. $\mathrm{CC}-\mathrm{Ti}$ 添加鋼板は他の 2 鋼種に比べ泡ガスが大気中へ 放散されにくい他の要因があるものと考えられるが，こ れについては現在調査中である.

( 3 ) $\mathrm{CO}_{2}, \mathrm{CO}$ および $\mathrm{NO}$ ガスの生成機構 : 各鋼種と も泡中ガスに $\mathrm{CO}_{2}, \mathrm{CO}$ および $\mathrm{NO}$ が微量存在してい る.これらは打もに鋼中 $[\mathrm{C}],[\mathrm{N}]($ カーバイド，ナイ トライドも含む)によって生成したと考えられる，金 子1) は泡原因はおもに酸洗後に生じたスマットであると 考えている.ささらに, $\mathrm{CC}-\mathrm{Ti}$ 添加鋼板でのスマットの 成分は $\mathrm{C}, \mathrm{S} ， \mathrm{O}$ および $\mathrm{Cu}^{3}$ または $\mathrm{Ti}, \mathrm{S}$ および $\mathrm{P}^{12)}$ であるといわれており，これらの酸化物系ガスもほうろ うの泡の原因になると考えられる。

一方，豊島ら ${ }^{2}$ は泡原因として鋼中に残留する炭素と 釉薬中および焼成需囲気中の酸素が仪忍して式( 7 ) ( 9 ) に示す $\mathrm{CO}$ ガスおよび $\mathrm{CO}_{2}$ ガスが生成されること により発生すると推定している. 式（８)は一般に，一回 掛けほうろうで起こりやすいとされている化学仪忍であ る.

しかし，ほうろう用冷延鋼板の $\mathrm{C}$ 㧍よび $\mathrm{N}$ 成分は一 般に極めて少なく，かつ，本研究結果でもこれらの酸化 物は微量であることがわかった。したがって、これらの 酸化物がほうろうの泡の原因ではないと考えられ，前記 各文献とは異なるものである，すなわち，泡の生成機構 は鋼中 [C] および [N]による反㐫もわずかに寄与し ているが，その主な生成機構は IC-Cap および CC-Hi 〔0]鋼板では式( 4 )の水と鋼板表面との店応であり， $\mathrm{CC}-\mathrm{Ti}$ 添加鋼板では水と鋼极表面との反応および空気 であると考えられる。

以上から，鋼種別の泡中ガスの量的関係を，ほうろう の泡生成機構を加味して要約すると以下のようになる.

(1) IC-Cap および CC-Hi [O] 鋼极 : $\mathrm{H}_{2} \mathrm{O}$ (フリット 中の水分, 焼成炉中の水分 $)+\mathrm{Fe} \gg$ フリット粒子間の 空気>鋼中 $[\mathrm{C}]+\mathrm{H}_{2} \mathrm{O}$

(2) CC- $\mathrm{Ti}$ 添加鋼板: $\mathrm{H}_{2} \mathrm{O}+\mathrm{Fe}$ ，空気（酸洗による結 晶粒界の腐食溝中の空気およびフリット粒子間の空気） $\gg$ 鋼中 $[\mathrm{C}]+\mathrm{H}_{2} \mathrm{O}$

\section{$4 \cdot 4 \mathrm{CC}-\mathrm{Ti}$ 添加鋼板の酸洗による結晶粒界の優先腐食}

今回調查した 3 鋼種のうち $\mathrm{CC}-\mathrm{Ti}$ 添加鋼板は硫酸酸 洗による結晶粒内の腐食はわずかであるが，結晶粒界が 優先的に腐食される．Photo. 3 は各鋼種を $10 \%$ 硫酸液 で $70^{\circ} \mathrm{C} ， 5 \mathrm{~min}$ 酸洗後の鋼板表面を SEM で観察したも のである. CC-Ti 添加鋼板は他の 2 鋼種に比べ粒界が 異常に浸食されているのがわかる.

この原因として CC-Ti 添加鋼板は他の鋼種に比べ約 

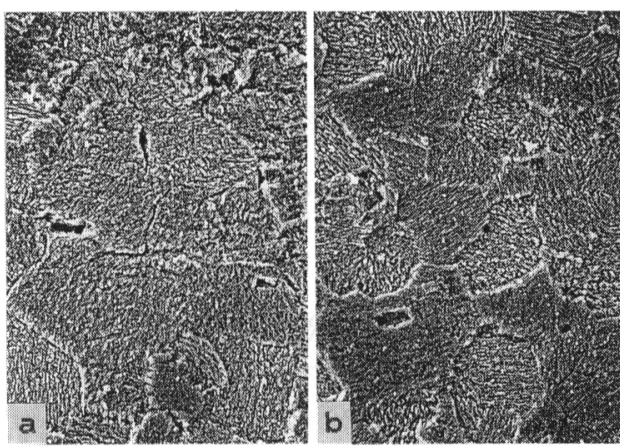

a) IC-Cap b) $\mathrm{CC}-\mathrm{Hi}[\mathrm{O}]$

c) $\mathrm{CC}$ - $\mathrm{Ti}$-bearing

Photo. 3. SEM micrographs of enamelling steel sheets after pickling for $5 \mathrm{~min}$ at $70^{\circ} \mathrm{C}$ in $10 \% \mathrm{H}_{2} \mathrm{SO}_{4}$ solution.
1 4 $\mu \mathrm{m}$ 径の硫化物系介在物が多く（1 100 個/ $\left.\mathrm{mm}^{2}\right)$, 粒界にこの介在物ないしは鋼中〔S〕が多いためと考え られる。

以上の結果から， $\mathrm{CC}-\mathrm{Ti}$ 添加鋼板の泡中ガスを減少 させる方法として，(1)粒界が優先的に腐食されにくい鋼 板の製造, (2)酸洗時間の短縮, 酸液濃度および酸洗浴温 の低下などが考えられる.

\section{5. 結言}

連続鋳造の $\mathrm{Ti}$ 添加ほうろう用冷延鋼板の泡発生原因 を究明するため，3 鋼種に両面直接一回掛けし，それら のほうろう層から抽出したガスをがスクロマトグラ フィーと質量分析を行った。さらに，酸洗およびほうろ う後, 鋼板の断面を検鏡し, 各鋼種別のほうろう工程に おけるガスの生成機構を究明した。その結果,

( 1 ) ほうろう層の泡中ガスは $\mathrm{H}_{2}$ および $\mathrm{N}_{2}$ が主体 で, $\mathrm{CO}, \mathrm{CO}_{2}, \mathrm{Ar}$ および $\mathrm{O}_{2}$ も微量存在する.

( 2 ) CC- Ti 添加鋼板は $\mathrm{H}_{2}$ および $\mathrm{N}_{2}$ がそれぞれ約 $53 \%$ および約 $46 \%$ で,これらのガスはフリット中の水, 焼成炉中の水と鋼板表面との反応によって生成した $\mathrm{H}_{2}$ と粒界腐食溝およびフリット粒子間にトラップされた空 気（おもに $\mathrm{N}_{2} ）$ により生成したものである．酸洗時間
を短くすると泡中の $\mathrm{N}_{2}$ ガスは減少する傾向にある.

(3) 一方, IC-Cap おょよひ CC-Hi $[\mathrm{O}]$ 鋼板は $\mathrm{H}_{2}$ が 主成分（約 $90 \%$ ）で，前記 $\mathrm{H}_{2}$ と同じ反応で生じたも のと考えられる.

最後に本研究をまとめるにあたって適切な御助言をい たたいた新日本製鉄(株)第二技術研究所薄板研究セン ター所長加藤弘博士, 主幹研究員秋末治博士および八幡 製鉄所品質管理部松田真之氏に深く感謝致します.

\section{文献}

1 ）金子堅次郎: 金属表面技術, 23 (1972), p. 282

2 ) 豊島清三, 松倉亀雄: セラミックス, 3 (1968), p. 265

3 ) 大沢正己, 吉田 誠, 松田真之, 矢野義成: 私信

4 ) S. E. Freeman and V. W. Meloche: J. Am. Ceram. Soc., 18 (1935), p. 123

5 ) D. G. Moore and M. A. Mason: J. Am. Ceram. Soc., 36 (1953), p. 241

6 ) P. K. Chu, J. H. Keeler and H. M. Davis: J. Am. Ceram. Soc., 36 (1953), p. 48

7 ) 藤永太一郎, 桑本 融: 実験化学講座続 9 ガスクロマトグ ラフィー（日本化学会編）（1965）, p. 159 [丸善]

8) W. W. Higgins: Ceram. Ind., 37 (1941), p. 48

9 ) W. A. Deringer: J. Am. Ceram. Soc., 26 (1943), p. 151

10) D. G. Moore: J. Am. Ceram. Soc., 35 (1952), p. 33

11）理科年表（東京天文台編纂）（1986）, p. 169 [丸善]

12) 安田 顕, 伊藤健治, 西田 稔, 高橋順介, 佐藤広武: 鉄と銅，69 (1983), S 1367 